African Crop Science Journal by African Crop Science Society is licensed under a Creative Commons Attribution 3.0 Uganda License. Based on a work at www.ajol.info/ and www.bioline.org.br/cs DOI: http://dx.doi.org/10.4314/acsj.v25i1.4S

\title{
LAND USE/COVER CHANGE PATTERNS IN HIGHLAND ECOSYSTEMS OF LAKE BUNYONYI CATCHMENT IN WESTERN UGANDA
}

\author{
C.L. KIZZA, M.M. TENYWA, J.G.M. MAJALIWA ${ }^{1}$, F. KANSIIME ${ }^{2}$, M. MAGUNDA ${ }^{3}$, \\ B. NAKILEZA ${ }^{1}$, B. BARASA ${ }^{4}$, G. GABIRI, E. SEBULIBA ${ }^{5}$ and J. NAMPIJJA ${ }^{5}$ \\ Department of Agricultural Production, College of Agricultural and Environmental Sciences, Makerere \\ University, P. O. Box 7062, Kampala, Uganda \\ ${ }^{1}$ Department of Geography, Geo-Informatics and Climatology, College of Agricultural and Environmental \\ Sciences, Makerere University, P. O. Box 7062, Kampala, Uganda \\ ${ }^{2}$ Department of Environmental Management, College of Agricultural and Environmental Sciences, Makerere \\ University, P. O. Box 7062, Kampala, Uganda \\ ${ }^{3}$ National Agricultural Research Laboratories (NARO), P. O. Box 7065, Kampala, Uganda \\ ${ }^{4}$ Geographical Information Systems Centre, Makerere University \\ ${ }^{5}$ Les Rams Consult Ltd, Kampala, Uganda \\ Corresponding author: kizluswata@gmail.com
}

\begin{abstract}
Land use and cover changes influence the livelihood and degradation of fragile ecosystems. The extents of these changes in pattern were investigated in Lake Bunyonyi Catchment which lies in the South Western Highlands of Uganda. The dynamics and magnitude of land use and cover changes were assessed using Landsat (TM/ETM+) satellite images and collection of socio-economic data through interviews. The images were processed and analysed using the mean-shift image segmentation algorithm to cluster and quantify the land use and cover features. The study noted that in the assessment period 1987-2014, the small-scale farmlands, open water and grasslands remained quasi constant; while the woodlots followed a quadratic trend, with the lowest acreage experienced in 2000. The tropical high forests and wetlands cover types experienced significant decline over the years $(\mathrm{P}<0.05)$. Patches of small-scale farmlands, woodlots, and wetland interchangeably lost or gained more land dependant on climate variability. Even though the tropical high forest lost more than it gained, it only gained and lost to small scale farmland and woodlots; while grassland mainly lost to small scale farmland and woodlots.
\end{abstract}

KeyWords: Land degradation, landsat images, land-use/cover dynamics, South-western Uganda

\section{RÉSUMÉ}

L'occupation du sol et les changements de couverture influencent la subsistance et la dégradation des écosystèmes fragiles. La tendance des niveaux de ces changements étaient évaluée dans le basin versant du lac Bunyonyi qui relie les régions montagneuses du Sud-Ouest d'Ouganda. Les dynamiques et l' envergure d'utilisaton de la terre et les changements de couverture étaient évaluées en utilisant les images du satellite Landsat (TM/ETM+) et la collecte des données socio-économiques à travers des interviews. Les images étaient traitées et analyées en utilisant l'algorithme de segmentation de passage-moyen-d'image pour grouper et quantifier les occupations du sol et les caractéristiques de la couverture. L'étude a montré que dans la période d'évaluation de 1987-2014, la petite étendue de terres cultivables, l'eau libre et les prairies sont demeurées quasi constantes; tandis que les terres boisées ont suivi une tendance quadratique, avec la plus petite superficie observée en l'an 2000. Les grandes forêts tropicales et les zones humides ont expérimenté un déclin significatif au cours des années $(\mathrm{P}<0.05)$. Les petites parcelles de terres agricoles, les terres boisées, et les zones humides indistinctement ont perdu et gagné 
plus de terres dépendamment de la variabilité climatique. Bien que la grande forêt tropicale aie perdu plus qu'elle en a gagnée; elle a seulement perdu de très petites étendues de terres agricoles et boisées; alors que les prairies ont principalement perdu de très petites étendues de terres agricoles et boisées.

Mots Clés: Dégradation du sol, images de Landsat, occupation du sol/dynamique de la couverture, Sud-Ouest d'Ouganda

\section{INTRODUCTION}

Sustainable land use management of the farming systems of Lake Bunyonyi catchment in Kigezi highlands of Southwestern Uganda hinges on improved understanding of land use/ cover change patterns influencing degradation of fragile ecosystems. Lake Bunyonyi catchment is an important ecosystem, supporting agriculture and provisioning of other ecosystem services to the livelihoods in the region (Kabale and Kisoro district). However, with increased population density and growth rates (UBOS, 2012), poor land management and the type of terrain (Magunda and Majaliwa, 2002), there is increasing evidence of land use/cover changes reported due to transformation of natural vegetation into farmlands, grazing lands, human settlement and urban centres (Bolwig, 2002, Maitima et al., 2009, Barasa et al., 2010, Majaliwa et al., 2015, Bizoza, 2015). These changes are cause of declining biodiversity (Darkoh, 2003), change in ecosystem services, catchment hydrology, local climate variation, food insecurity, and change in pollution loading into surface waters (Azanga, 2013).

Up-to Uganda's independence, the catchment was covered with well-managed terraces, but are now destroyed and very few households are adopting best soil and water conservation practices (Pander et al., 2002). Besides, the terrain within the catchment which is generally mountainous, with steep slopes and deep valleys (Were, 1997), has contributed immensely to land use/cover changes. In addition, the current demographic pressure has inevitably led to rampant land fragmentation and increased encroachment on the otherwise marginal land for food production (Carswell, 1997).
Poor land management in this area is also steadily influencing land use/cover changes. For example, after soils have eroded, the resultant bare soils are preferred for Eucalyptus plantations, thus threatening occurrence of famine in an area hitherto known as one of the major food baskets in Uganda (Baraire, 2013). However, the limited knowledge on the extent and trajectory of land use and cover changes in Lake Bunyonyi catchment is impacting on arable land leading to its gradual reduction consequently posing a serious risk of food insecurity not only in Lake Bunyonyi Catchment but the country as a whole. The land use changes in Kabale have been reported to have led to the alteration of climatic and weather patterns (Barakagira and Kateyo, 2008). The objective of this study was to determine land use/cover changes and also establishes the land use/cover dynamics in Lake Bunyonyi Catchment in South-Western Highlands of Uganda to inform proper land use management.

\section{MATERIALS AND METHODS}

The study area. The study was carried out in Lake Bunyonyi catchment in Uganda (Fig. 1), located at $1^{\circ} 20^{\prime} 42^{\prime \prime}$ South and $29^{\circ} 51^{\prime} 1^{\prime \prime}$ East. It is a highland area characterised by several hills, with steep slopes and deep valleys covering an area of approximately $334 \mathrm{~km}^{2}$. The altitude ranges between $1700-2200 \mathrm{~m}$ above sea level. The mean annual minimum and maximum temperatures are 12.8 and $21.4^{\circ} \mathrm{C}$, respectively; with a mean of $16.1^{\circ} \mathrm{C}$; and mean annual rainfall is $884 \mathrm{~mm}$ (Kristan et al. 2008). The soils are mainly ferralitic, volcanic and histic (Chemining'wa et al., 2005) underlain by the oldest pre-cambium age variety of metamorphic largely granitoid 


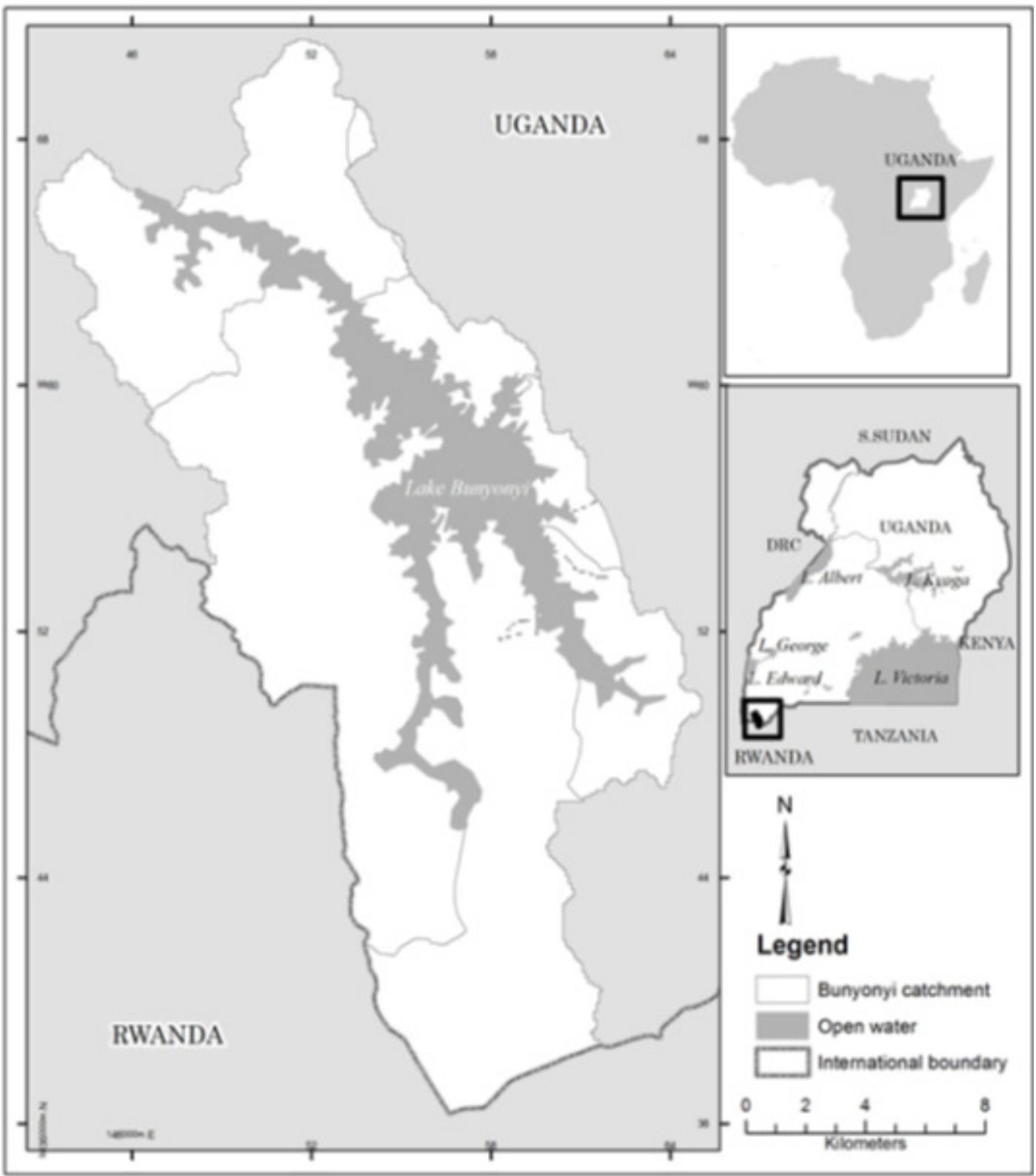

Figure 1. Map of the study area, Lake Bunyonyi catchment. 
rocks, acid gneisses, schists and foliated granites.

Agriculture is the leading economic activity and the major crops grown include sweet potatoes, beans, sorghum, Irish potatoes, field peas, maize, wheat and vegetables (Osiru, 2006).

Land use/cover characterisation. The study acquired and utilised a series of multi-temporal (cloud cover $10 \%$ ) Landsat images $(30 \mathrm{~m}$ resolution) downloaded from the Glovis website (http://glovis.usgs.gov/) for periods 1987, 1999, 2005 and 2014 to characterise land use/cover changes within L. Bunyonyi catchment. Several studies have demonstrated the usefulness of Landsat images in the characterising landscape, land use and cover types (Alberti et al., 2004; Yuan et al., 2005). The downloaded images were taken in the month of January, which is normally a dry month as observed from the precipitation records for the last 30 years in the catchment (The World Bank Group, 2017). This month was good for the spectral distinction of features in all images. The images used in this study were selected because of their availability, coverage and low cloud coverage to facilitate information extraction, given the local climatic conditions within the catchment. The images were atmospherically corrected by using Dark Object Subtraction procedures to minimise atmospheric errors that would limit information extraction. They were then filtered to remove noise following the Majority Filtering Method $(3 \times 3)$ of image enhancement (Guerschman et al., 2003).

The heterogeneity of features within the catchment was distinctively separated by segmentation (Fig. 2). The pre-processed images were analysed using an image segmentation algorithm. A mean shift image segmentation algorithm was carried out following Zhong and Zhao (2005) and Friedman et al. (2003) procedures for feature extraction from remotely sensed data. A mean shift algorithm is useful for damping tonality differences in local features within the images.
The catchment land use/cover types are described based on field observations (Table 3 ). Field observations were used as a basis for developing the image classification scheme, through categorisation of land use and cover classes. The scheme was customised because of spectral reflectance of land use types and their distribution within the catchment.

The National Forestry Authority Biomass Study results of 2003 for land use/cover types that occurred in Lake Bunyonyi catchment and ground-truthed data, were considered in order to improve the image classification accuracy. A total of 120 ground-truthed points, covering the broad land-use/cover classes, were collected using a Garmin Global Positioning System (3 $\mathrm{m}$ accuracy) from the abovespecified land use/cover types in Table 2. The re-classified images were validated for accuracy assessment using both field observational data and Google Earth images.

In addition, key informants including 4 Local Council (LC) 3 leaders, 3 Sub-county and 6 Parish chiefs and 3 LC 3 production officials and at least two senior citizens (aged $>50$ years) having stayed in the area for at least 30 years from the sub-counties within the catchment were interviewed for the reconstruction of the past land-use/cover. The National Land use/Cover Maps of 1986 and 2008 for Uganda, developed by the National Forestry Authority, were also used in the reconstruction process. Overall, image classification accuracy was computed using an automated error matrix algorithm in Idrisi Selva software. However, image accuracy that was achieved varied with the classified images (Table 3).

Land use/cover change pattern. The transition of land use/cover was obtained through cross tabulation computation of classified land use/cover images for two consecutive time series. The pattern in land use/cover change was obtained using regression techniques. Land use/cover data for different periods of time were used for this purpose. 


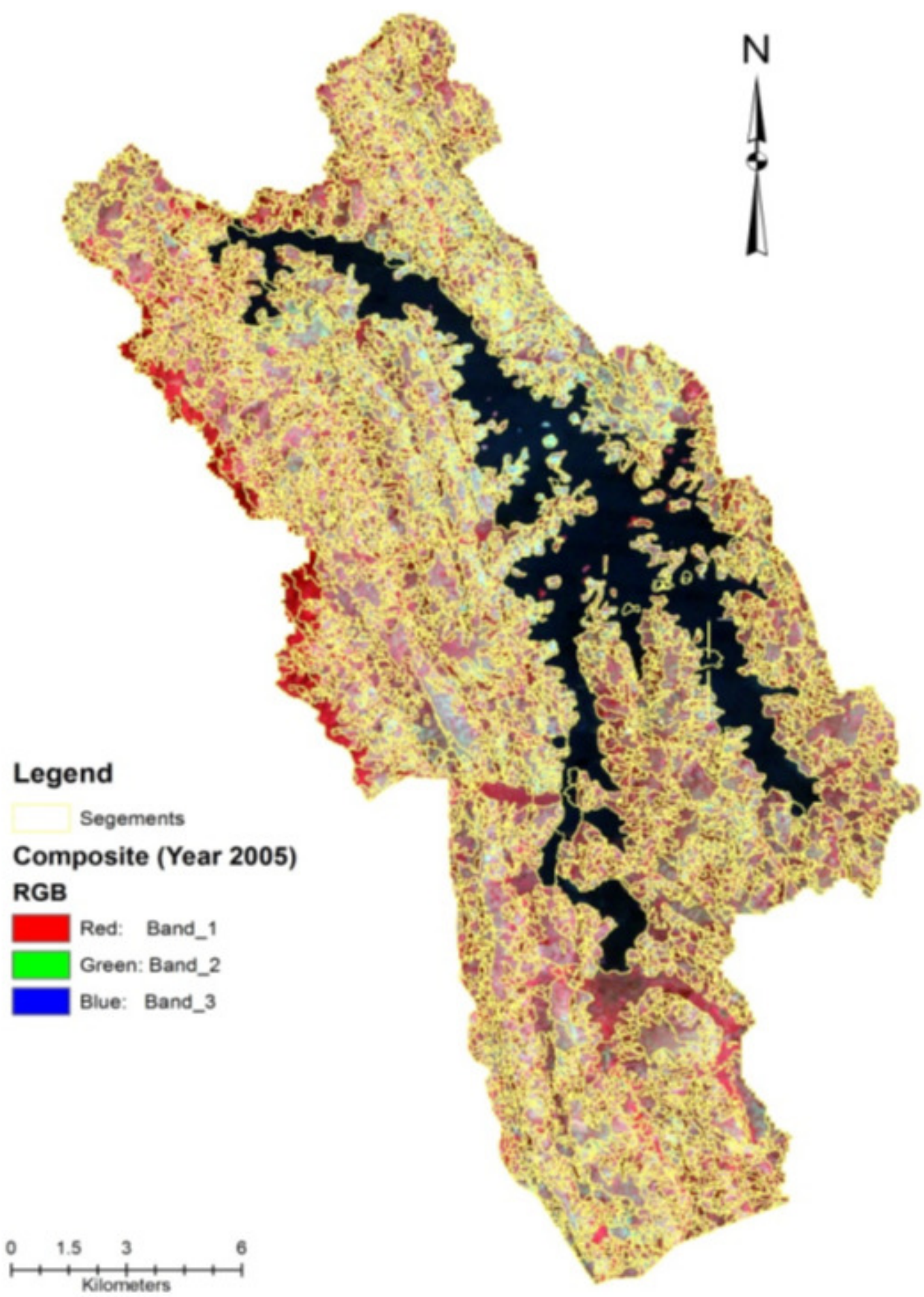

Figure 2. Segmented image 2005 for Lake Bunyonyi Catchment in Southwestern Uganda. 
TABLE 1. Landsat satellite image specifications used in land-use/cover classification in the Lake Bunyonyi catchment

\begin{tabular}{llcc}
\hline Landsat sensor & Path/Row & Year & Band combinations \\
\hline Landsat TM & $173 / 61$ & 1987 & $4,3,2$ \\
Landsat ETM & $173 / 61$ & 1999 & $4,3,2$ \\
Landsat ETM+ & $173 / 61$ & 2005 & $4,3,2$ \\
Landsat OLI/TIRS & $173 / 61$ & 2014 & $3,2,1$ \\
\hline
\end{tabular}

TABLE 2. Description of land use / cover classes used in the Lake Buntonyi catchment image classification

\begin{tabular}{ll}
\hline Land use/cover types & Description \\
\hline Small scale farmlands & Small size land pieces, cropped with both annuals and perennials mainly for subsistence \\
Tropical High Forest & Natural rainforest with many species of plants and animals \\
Wetlands & Permanently and seasonally waterlogged areas \\
Open water & Water body free of any vegetation occurring throughout the year \\
Woodlots & Plantation woodlots especially Eucalyptus and Pines \\
Grassland & Area covered mainly by naturally occurring grasses and grass-like vegetation
\end{tabular}

TABLE 3. Variations in the image accuracy over the years between 1987 and 2014 for Lake Bunyonyi catchment

\begin{tabular}{lc}
\hline Year & Overall image classification accuracy $(\%)$ \\
\hline 1987 & 78 \\
1999 & 81 \\
2005 & 83 \\
2014 & 92 \\
\hline
\end{tabular}

\section{RESULTS}

Land use/cover change. Table 4 summarises land use/cover between the years 1987 and 2014, comprising of small scale farmland, tropical high forest, grassland, open water, wetland and woodlot. Over these years, the most dominant land use type was small-scale farmland followed by woodlots. Open water was the third most dominant land cover followed by wetlands while the least dominant was grassland followed by tropical high forest.

Figure 3 shows how the area under these different land-use/covers fluctuated over the last 27 years. However, grassland and open water remained quasi-constant during this period $(\mathrm{P}>0.05)$. The small scale farms tended to increase linearly $\left(R^{2}=0.607\right)$, but the increase was not significant $(\mathrm{P}>0.05)$. Woodlot followed a quadratic trend $(0.07 \mathrm{t} 2-1.80 \mathrm{t}+58.2$; $\mathrm{R}^{2}=0.94$ ), with a minimum around the year 2000. Tropical forest and wetland significantly decreased over the years $(\mathrm{P} \leq 0.02)$. The tropical forest declined by $0.18 \mathrm{~km}^{2} \mathrm{yr}^{-1}$, while the wetland declined $0.47 \mathrm{~km}^{2} \mathrm{yr}^{-1}$.

Change dynamics for various periods. Figure 4 shows the images of how the land use/covers had changed from 1987 to 2014. The interpretation of the images is presented 
TABLE 4. Percentage land area under each land use/cover 1987, 1999, 2005 and 2014 for Lake Bunyonyi catchment in southwestern Uganda

\begin{tabular}{|c|c|c|c|c|c|c|c|c|}
\hline \multirow{2}{*}{$\begin{array}{l}\text { Period } \\
\text { Land use/cover types }\end{array}$} & \multicolumn{2}{|c|}{1987} & \multicolumn{2}{|c|}{1999} & \multicolumn{2}{|c|}{2005} & \multicolumn{2}{|c|}{2014} \\
\hline & $\mathrm{km}^{2}$ & $\%$ & $\mathrm{~km}^{2}$ & $\%$ & $\mathrm{~km}^{2}$ & $\%$ & $\mathrm{~km}^{2}$ & $\%$ \\
\hline Small scale farmlands & 189.1 & 56.6 & 215 & 64.4 & 211.2 & 63.2 & 215.7 & 64.6 \\
\hline Tropical High Forest & 12.4 & 3.7 & 9.7 & 2.9 & 9.5 & 2.8 & 7.2 & 2.2 \\
\hline Grasslands & 0.2 & 0.1 & 0.15 & 0.04 & 0.4 & 0.1 & 0.09 & 0.09 \\
\hline Open water & 52.5 & 15.7 & 50.8 & 15.2 & 49.8 & 14.9 & 40.6 & 12.2 \\
\hline Wetlands & 21.4 & 6.4 & 13.3 & 4.0 & 11.9 & 3.6 & 8.7 & 2.6 \\
\hline Woodlots & 58.6 & 17.5 & 45.1 & 13.5 & 51.5 & 15.4 & 61.8 & 18.5 \\
\hline
\end{tabular}

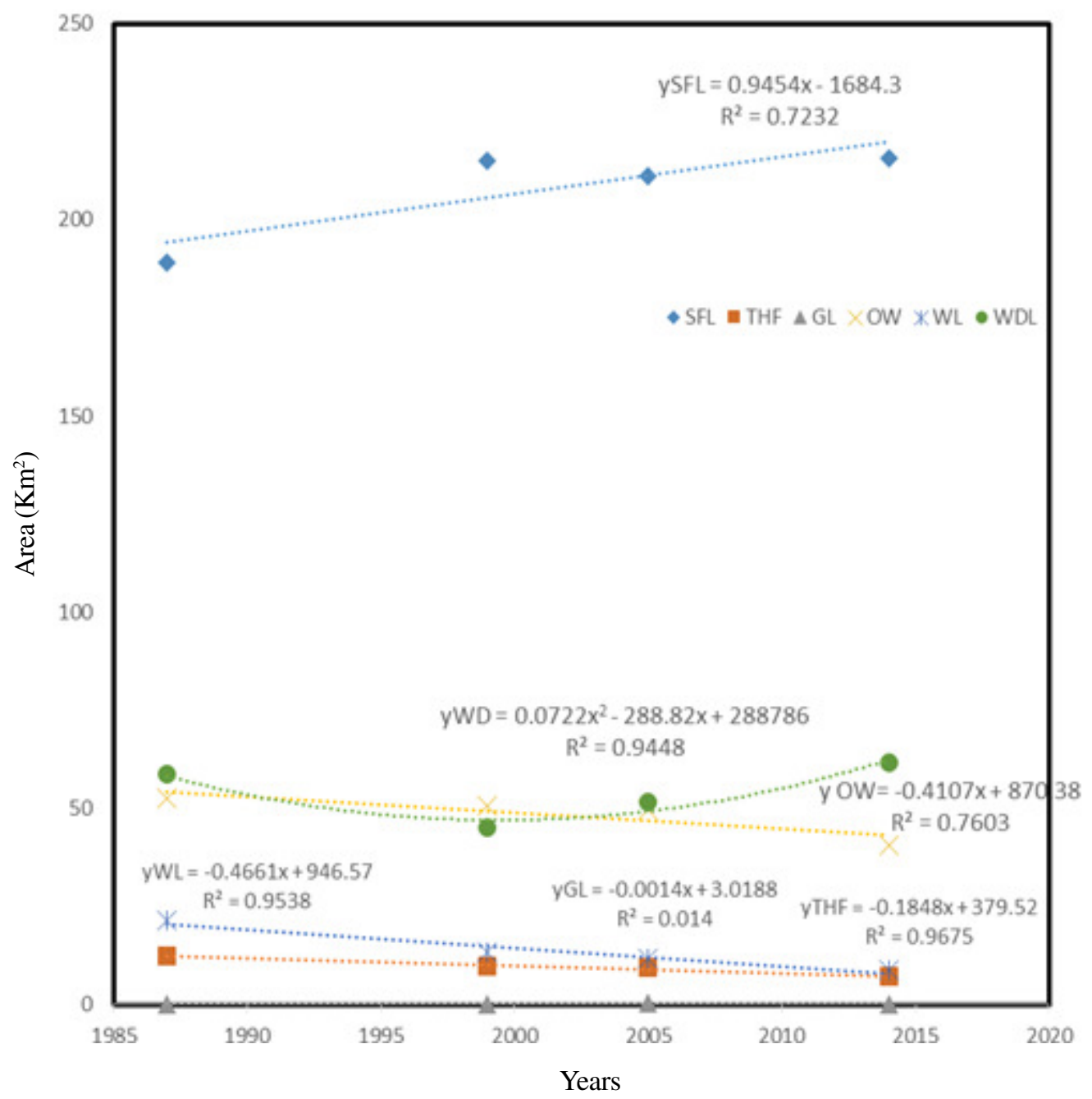

Figure 3. Trend of land use/cover change during 1987-1999 and 2005-2014 periods. SFL = Small scale farmland, $\mathrm{THF}=$ Tropical High Forest, GL $=$ Grassland, OW $=$ Open water, $\mathrm{WL}=$ Wetland, $\mathrm{WDL}=$ Woodlots. 


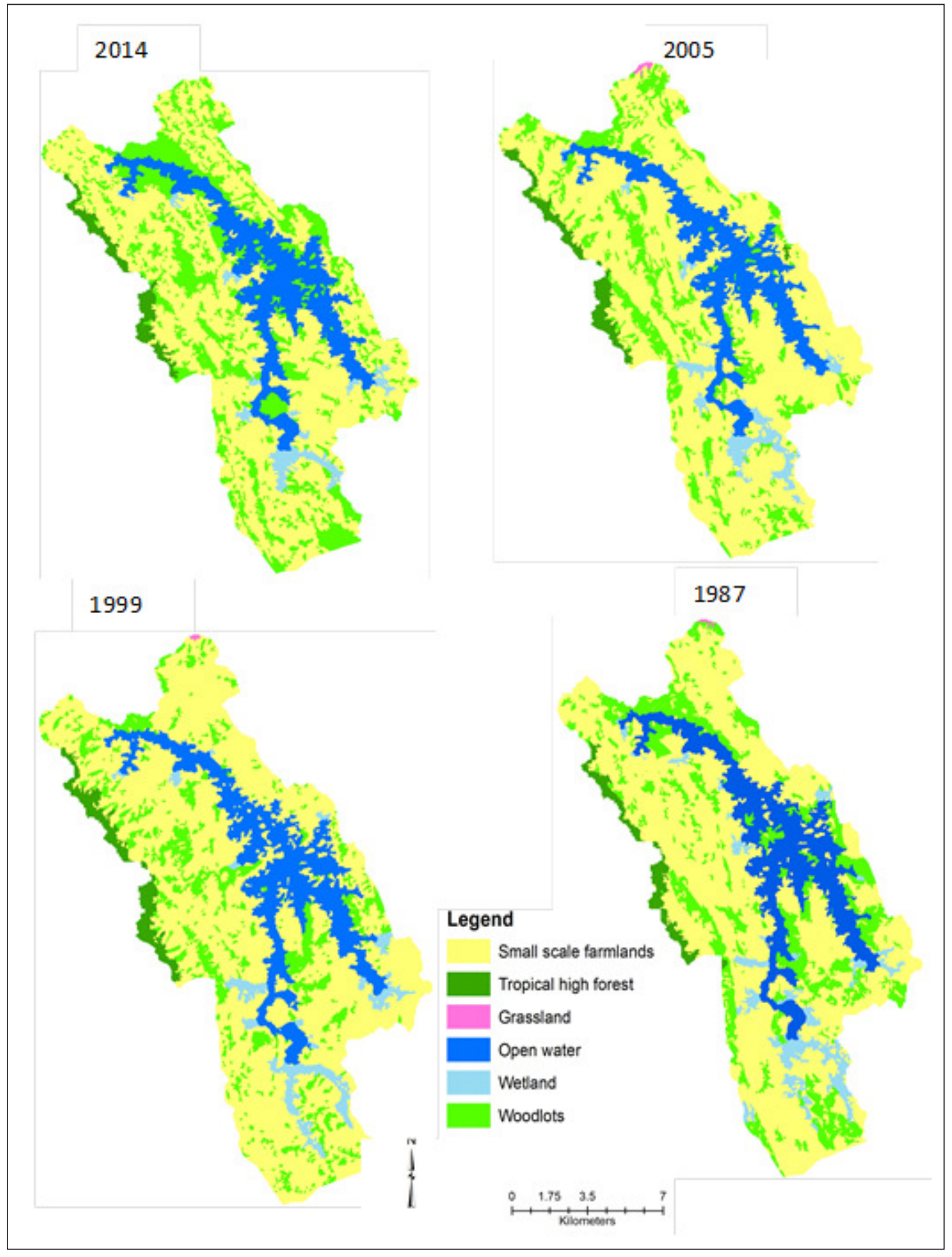

Figure 4. Land use/cover map for years 1987, 1999, and 2014 for Lake Bunyonyi catchment in Uganda. 
in the respective tables. Table 5 shows land use/cover change matrix for 1987 to 1999. During this period, small-scale farms gained more land $\left(46.5 \mathrm{~km}^{2}\right)$ against a loss of 44.78 $\mathrm{km}^{2}$. Its gain was from all the land-use/covers but the bulk was mainly from the woodlot, and lost mainly to the woodlot, tropical high forest and wetland. The woodlots experienced more loss $\left(43.1 \mathrm{~km}^{2}\right)$ than gain $\left(37.6 \mathrm{~km}^{2}\right)$. The woodlots mainly gained from and lost to small-scale farmland. A net gain of $7.1 \mathrm{~km}^{2}$ against a loss of $0.7 \mathrm{~km}^{2}$ was realised between 1987 and 1999 in the tropical highland forest cover. Over 96 and $81 \%$ of the gain and loss, respectively, in tropical highland forests were from and too small-scale farmland.

Open water had a gain of $3.36 \mathrm{~km}^{2}$, as opposed to the loss of $5.61 \mathrm{~km}^{2}$. It gained from three land uses/covers, namely small-scale farmlands $\left(1.8 \mathrm{~km}^{2}\right)$, woodlots $\left(1.26 \mathrm{~km}^{2}\right)$ and wetlands $\left(0.26 \mathrm{~km}^{2}\right)$. It lost to the same land uses/covers at $4.7 \mathrm{~km}^{2}, 0.55 \mathrm{~km}^{2}$ and 0.27 $\mathrm{km}^{2}$, respectively.

Although there was neither a net gain nor loss in the size of wetlands, the sharing was between three land uses, namely small scale farmlands, woodlots and open waters. Grasslands only gained from one land use of woodlots but lost to two land uses of smallscale farmland and woodlots with the former taking over $81 \%$.

Table 6 shows land use/cover change matrix for the period between 1999 and 2005 . It indicates that small-scale farmland gained variably from all the land use/covers. It gained $26.02 \mathrm{~km}^{2}$ from woodlots $(71.7 \%), 5.75 \mathrm{~km}^{2}$ (15.9\%) from wetlands, $3.25 \mathrm{~km}^{2}(9 \%)$ from open water, $1.23 \mathrm{~km}^{2}(3.4 \%)$ from tropical high forest and $0.0245 \mathrm{~km}^{2}(0.1 \%)$ from grasslands. The loss was mainly to woodlots $31.92 \mathrm{~km}^{2}(78.7 \%)$, wetlands $4.35 \mathrm{~km}^{2}$ $(10.7 \%)$, open waters $3.12 \mathrm{~km}^{2}(7.7 \%)$, tropical high forest $0.97 \mathrm{~km}^{2}(2.4 \%)$ and grassland $0.18 \mathrm{~km}^{2}(0.04 \%)$. Whereas the woodlots gained from all the land use/covers, they lost to four, but did not lose to open water. The gain and loss was majorly from and to

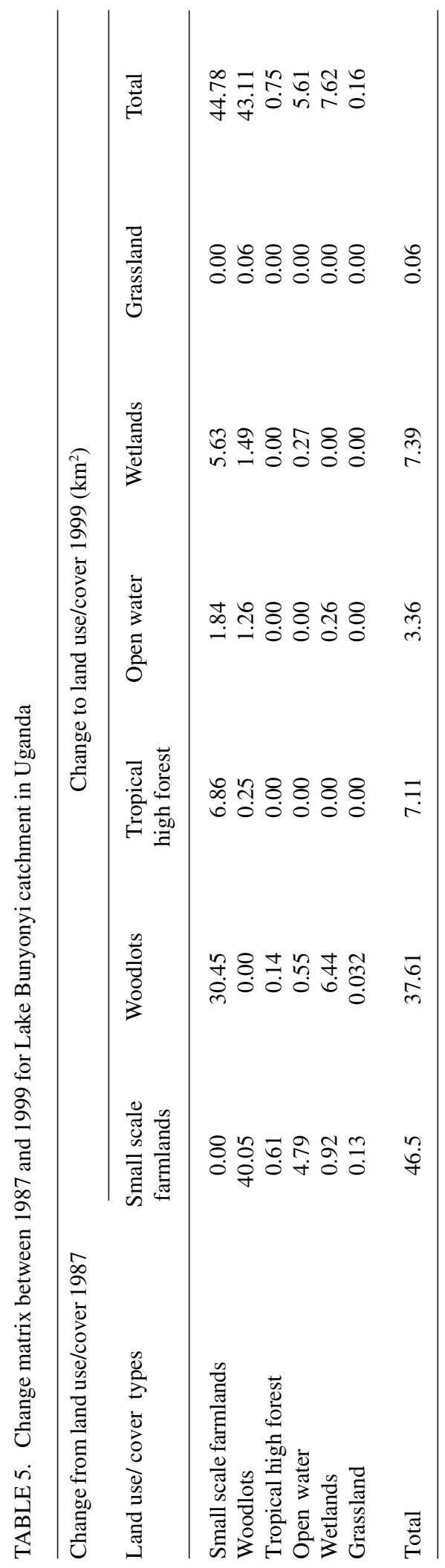


small scale farmlands 26.1 and 31.9, representing $94.4 \%$ and $95.77 \%$, respectively.

The tropical high forest only gained and lost from and to two land uses of small-scale farming and woodlots. The gain was 69.3 and $30.7 \%$ for small scale farming and woodlots respectively; while the losses were $76.88 \%$ and $23.1 \%$, respectively. The open water gained only from small-scale farming $(90.1 \%)$ and wetland (9.1\%); while it lost to three land use/ covers small-scale farming (76.47\%), woodlots (17.4\%) and wetlands (6.1\%). Wetlands gained and lost to the same land uses/ covers of small-scale farmland (82.7 and $84.3 \%$ ), woodlots (12.3 and $11.1 \%$ ) and open water (4.9 and $45.5 \%)$. Grasslands only gained from one land use/cover of small-scale farmland; while it lost to two land use/covers of small scale farming $\left(0.024 \mathrm{~km}^{2}\right)$ and woodlots $\left(0.006 \mathrm{~km}^{2}\right)$.

The land use/cover change dynamics between 2005 and 2014 is presented in Table 7. There was a net gain of $4.2 \mathrm{~km}^{2}$ under small scale farms during this period. The largest gain was from woodlots, followed by wetlands and tropical high forest. However, it lost to woodlot followed by open water and negligible area to wetland and tropical high forest. It did not lose to the grassland. Over $95 \%$ of the loss and gain in woodlot was from and to small-scale farmland. Whereas it gained from all the land use/covers, it did not gain from two, namely wetland and grassland. The loss in the tropical high forest was significantly higher than the gain. The little gain was from only two land uses of small-scale farmland and woodlot. It again lost to the same land uses but predominantly small-scale farmland.

Unlike tropical highland forest, the open water gained more than it lost. Whereas it gained from two land uses (small-scale farmland and woodlots), it lost to three (smallscale farmland, woodlots and though little to wetlands). Wetland almost never gained compared to the loss. The only small gain was from farmland $\left(0.08 \mathrm{~km}^{2}\right)$ and from open water $\left(0.03 \mathrm{~km}^{2}\right)$. The major wetland loss $(94.8 \%)$ went to small-scale farmland and small 
portions of 2.3 and $2.8 \%$ were lost to woodlots and open water, respectively. Whereas grassland never gained from any other land use/cover, it suffered a loss to small-scale farmland (45\% of the loss) and woodlots $55 \%$ of the loss).

\section{DISCUSSION}

Between the years 1987 and 2014 Lake Bunyonyi catchment had six major land use/ cover including small-scale farmland, tropical high forest, grassland, open water, wetland and woodlot (Table 4). This observation is in line with the National Biomass Study (1996) and Majaliwa et al. (2015), and slightly different from observations from Bolwig (2002) who did not report open water, but instead had some bushland and large scale farming between 1954 and 1990s. The trend on small-scale farmland does not reflect what was observed by other authors in the region and other parts of Uganda (Majaliwa et al., 2010; Egeru and Majaliwa, 2009, Twongyirwe et al., 2011; Bagalwa et al., 2012).

Grassland and open water remained quasiuniform from 1987 to 2014 (Fig. 3) mainly because of the relatively small patches available, scarcity of cultivated land due to the increasing demographic pressure; while open water remained quasi-constant because most of the water under Lake Bunyonyi is known to be too deep (Briggs and Roberts, 2013); that scares away farmers from draining it.

The decline in the tropical high forest is attributed to increased human population in search for arable land (Bolwig, 2002; Carswell, 2002; Oslen and Berry, 2003). This resulted in widespread land fragmentation (Were, 1997; Nkonya 2004). However, due to limited nutrient inputs, part of converted farmlands from the forest were degraded and revertedly into woodlots. Similarly, the reduction in the wetland was due to drainage by farmers for crop cultivation and providing grassland for livestock (Sabiiti and Mutabazi, 2000). The woodlot did not follow a linear trend, having dropped to lowest levels in 2000, 
before it started to gradually increase. The drop in woodlot was caused by opening for smallscale farmland, timber and pole harvesting. The relative increment in woodlots since 2000 is attributed to farmers' utilisation of the highly degraded soils on the hill slopes (Mugisha and Alobo, 2012) that cannot support crops (Gerritis, 1999) for eucalyptus plantation.

Land use/cover in the Lake Bunyonyi fluctuated between 1987 and 2014 (Tables 5, 6 and 7). Patches of small scale farmlands, woodlots and wetland changed from one use/ cover to another from one period to another. Small scale farmland gained from all the land use/covers, but lost to all the land use/cover apart from grassland. Small-scale farmland mainly exchanged its acreage with the woodlots (Tables 5, 6 and 7). Part of the woodlots going to the small-scale farmland, was influenced partially by demographic pressure (Carswell, 2002). It could also have been influenced by the high land fragmentation (Were, 1997; Puhala, 2009). In addition, land degradation due to nutrient depletion (Bolwig 2002; Bekunda and Manzi 2003; Nkonya et al., 2005) and soil erosion (Muyinza and Naguula, 2007) equally contributed.

The land gain and lose to small-scale farmland by the woodlots and gaining from the tropical high forest, is explained by the transition from the tropical high forest, to woodlot then to small-scale farmland as the gradual steps in natural forest encroachment. But the main driver of all these conversions as reported by Luoga et al. (2005) is a combination of socio-economic factors, levels of agricultural productivity and historical factors. The areas that had converted to smallscale farming from the tropical high forest ended up into woodlots as a result of exhaustion of the already low inherent soil fertility soils (Butler, 2012). However, the limited gain by the tropical highland forest mainly from small-scale farming was as a result of the re-gazetting exercise (Obua and Agea, 2010) that redefined the forest boundary.

Woodlots mainly on the hill slopes converted to woodlots (Tables 5, 6 and 7) because such soils could hardly support the traditional crops anymore (Bamwerinde, 1996), as they were too shallow with very low nutrient content (Muzira et al., 2014) and, thus the farmers resorted to growing Eucalyptus as a more suitable alternative land use (Majaliwa et al., 2015). The degradation of the hill slopes was as a result of poor management of the terraces (Kakuru and Peden, 1991). The conversion of wetlands to small-scale farmland was also reported by Carswell (2002) and has been a common practice mainly for growing vegetables (Barakagira and Kateyo, 2008) because wetland soils are relatively more fertile soils (Denny 1993; Bolwig, 2002) and as a source of water especially during the dry season.

Open water reduction was as a result of the siltation caused by soil erosion from the hill slopes. The siltation has been accelerated by the rampant degradation and reduction of the wetlands that used to protect the lake (Maclean et al., 2003). It was also partially caused by draining by farmers (Mafabi, 2000) in their search for arable land to increase agriculture. The small land size for grassland mainly in the lowlands was due to the high level of land fragmentation and competition with cropland. The further reduction in the size of grassland land was due to the duo purpose of fallowing and grazing (Carswell 2002) which later made these patches relatively more fertile and irreversibly became small-scale farmland.

\section{CONCLUSION}

The major land-use/covers in Lake Bunyonyi are small-scale agriculture, woodlot, tropical forest, grassland, wetland and open water. Small scale farmland, grassland and open water have not significantly changed from 1987 to 2014 period. The tropical high forest has declined gradually with time while woodlot has changed quadratically with time.

Patches of small scale farmlands, woodlots, and wetland changed to use/cover form one period to another. Although the 
tropical high forest lost more than it gained, it only gained and lost to small-scale farmland and woodlots; while grassland mainly lost to small-scale farmland and woodlots. In order to reduce on land use/cover change, the terraces that used to control land degradation should be rehabilitated and stabilised; while other soil and water conservation practices like trenches and grass bands, should be included within the terrace.

\section{ACKNOWLEDGEMENT}

The Sub-Saharan Africa Challenge Programme (SSACP) and Humid Tropics a CGIAR Research Program led by the International Institute of Tropical Agriculture (IITA) funded the study. Special appreciation also goes to the local and district government officials for facilitating the data collection processes.

\section{REFERENCES}

Alberti, M., Weeks, R. and Coe, S. 2004. Urban land cover change analysis in Central Puget Sound. Photogrammetric Engineering and Remote Sensing 70(9):1043 - 1052.

Azanga, E. 2013. Sediment and nutrient hotspot areas dynamics in selected microcatchment of Lake Tanganyika basin in Democratic Republic of Congo. Master Thesis, Makerere University, Kampala, Uganda.

Bagalwa, M., Zirirane, N., Pauls, S.U., Karume, K., Ngera, M., Bisimwa, M. and Mushagalusa, N. 2012. Aspects of the physico-chemical characteristics of rivers in Kahuzi-Biega National Park, Democratic Republic of Congo. Journal of Environmental Protection 3:1590-1595.

Barakagira, A. and Kateyo, E. 2008. Impacts of wetland drainage on domestic water supplies and peoples' livelihoods in Kabale district, Uganda. Paper presented at $12^{\text {th }}$ Biennial Conference of the International Association for the Study of Commons,
University of Gloucestershire, UK. http:// iasc $2008 . g l o s . a c . u k / c o n f e r e n c e \%$ 20papers/. Accessed on $14^{\text {th }}$ April 2016.

Barasa, B., Egeru, A., Okello, P., Mutuzo, F., 2010. Dynamics of land use/cover trends in Kanungu District, southwestern Uganda. Journal of Applied Science and Environmental Management 14:67-70.

Bekunda, M. and Manzi, G. 2003. Use of partial nutrient budget as an indicator of nutrient depletion in Highlands of south-western Uganda. Nutrient recycling in Agroecosystems 67:187-195.

Bizoza, A.R. 2015. Soil erosion and land tenure regularization in Rwanda: A historical perspective. Paper prepared for presentation at the "2015 World Bank Conference on Land and Poverty" The World Bank - Washington DC, March 2327, 2015. https://www.conftool.com/ landandpoverty2015. Accessed on $26^{\text {th }}$ April 2016.

Bolwig, S. 2002. Land use change and soil degradation in the Southwestern highlands of Uganda. A contribution to the strategic criteria for rural investments in productivity programme of USAID Uganda Mission, The International Food Policy Research Institute 2033 K Street, N.W. Washington, D.C. 20006.

Briggs, A. and Roberts, P. 2013. Uganda: The Bradt Travel Guide, $7^{\text {th }}$ Edition, Bradt Travel Guides Ltd, IDC House, Vale, Chalfont St. Peter, Bucks SL9 9RZ, England.

Butler, R. 2012. Soils and Nutrient recycling in rainforests. Accessed on $26^{\text {th }}$ August 2016 from: http://www.issc.ernet.in/ currsci/oct252001/936.pdf http:// www.iisc.ernet.in/currsci/oct252001/ 936.pdf

Buyinza, M. and Naguula, A. 2007. Adoption of Agroforestry Technology and Land Conservation Strategies in the Highlands of south-western Uganda. Makerere University Research Journal 002 (1): 1324. 
Carswell, G. 1997. Agricultural Intensification and Rural Sustainable Livelihoods: A 'Think Piece', IDS Working Paper 64, Brighton: IDS.

Carswell, G. 2002. Farmers and fallowing: Agricultural change in Kigezi District, Uganda. The Geographical Journal 168 (2): 130-140.

Chemining'wam G., Mulagoli, I., Mwonga, S., Ndubi, J., Tum, J. and Tulyamureeba, G. 2005. Kabale apples: Boom or Burst. A study to develop strategies to exploit market opportunities for apple farmers in Kabale, Uganda. www.icra-edu.org/file.php/124/ wd125.pdf. Accessed on $5^{\text {th }}$ April 2016.

Darkoh, M.B.K. 2003. Regional perspectives on agriculture and biodiversity in the drylands of Africa. Journal of Arid Environments 54:261-279.

Denny, P. 1993. Wetlands of Africa: Introduction. In: Lieth, H., Whigham, D.F., Dykyjavá, D. and Hejný, S. (Eds.). Handbook of Vegetation Science, Springer, 15/2, pp. 1-32.

Egeru, A. and Majaliwa, M. 2009. Land use/ cover change trend in Soroti District, Eastern Uganda. Journal of Applied Sciences and Environmental Management 13 (4):77-79.

Friedman, L., Netanyahu, N. S. and Shoshany, M. 2003. Mean shift-based clustering of remotely sensed data. In: Geoscience and Remote Sensing Symposium, 2003. IGARSS'03. Proceedings. 2003 IEEE International 6: 3432-3434.

Gerritis, A. 1999. Biodiversity for income generation. LEISA Magazine $15 \mathrm{n}^{\mathrm{o}}$ 3/4 December 1999. Accessed on $21^{\text {st }}$ October 2015 from: http://www.agricultures network.org/magazines/global/ agrobiodiversity/biodiversity-for-incomegeneration

Guerschman, J.P., Paruelo, J.M., Di Bella, C., Giallorenzi, M.C. and Pacin, F. 2003. Land cover classification in the Argentine Pampas using multi-temporal Landsat TM data. International Journal of Remote Sensing 24:3381-3402.
Kakuru, A. and D. Peden. 1991. Can contour hedgerows control soil erosion on steep lands of Southwest Uganda? In: Zake, J.Y.K., Tumuhairwe, J.K., Ochwoh, V., Tenywa, J.S., Nkwiine, S. Ssesanga, M., Hyuha, T. and E.N.B. Nsubuga (Eds.). Proceedings of the Eleventh Annual general meeting of the Soil Science Society of East Africa conducted in Mukono, Uganda.

Kristan, M., Abeku, T.A., Beard, J., Okia, M., Rapuoda, B., Sang, J. and Cox, J. 2008. Variations in entomological indices in relation to weather patterns and malaria incidence in East African highlands: implications for epidemic prevention and control. Malaria Journal 7 (231):14752875.

Luoga, E.J., Witkowski, E.T.F. and Ballkwill, K. 2005. Land cover and use changes in relation to institutional framework and tenure of land and resources in eastern Tanzania miombo woodlands. Environment Development and Sustainability 7: 96-98.

MacLean, I., Tinch, R., Hassal, M. and Boar, R. 2003. Social and economic use of wetland resources: a case study from Lake Bunyonyi, Uganda. Centre for Social and Economic Research on the Global Environment, Norwich.

Mafabi, P. 2000. The role of wetland policies in the conservation of waterbirds: The case of Uganda. Ostrich 71:96-98.

Magunda, M.K. and Majaliwa, J.G.M. 2002. A review of the effects of population pressure on watershed management practices in the Lake Victoria Basin. African Journal of Tropical Hydrology and Fisheries. pp. 7991.

Majaliwa, J.G.M., Twongyirwe, R., Nyenje, R., Oluka, M., Ongom, B., Serike, J., Mfitumukiza, D., Azanga, E., Natumanya, R., Mwerera, R. and Barasa, B. 2010. The effect of Land cover change on soil properties around Kibale National Park in Southwestern Uganda. Applied and Environmental Soil Science 10: 1-7, Article ID 185689. 
Majaliwa, M.J.G., Tenywa, M.M., Rao, K.P.C., Musana, B., Fungo, B., Bahiga, L., Mkangya, J., Kuule, M., Kamugisha, R., Kizza, C.L., Nampijja, J., Sebuliba, E., Nandozi, C., Barasa, B., Azanga, E., Nyamwaro, S.O., Mugabo, J., Buruchara, R., Oluwole, F., Karume, K. and Adewale, A. 2015. Soil fertility in relation to landscape position and land use/cover types: A case study of the Lake Kivu Pilot Learning Site. Advances in Agriculture 2015:20-28.

Maitima, J.M., Mugatha, S.M., Reid, R.S., Gachimbi, L.N., Majule, A, Lyaruu, H., Pomery, D., Mathai, S. and Mugisha, S. 2009. The linkages between land use change, land degradation and biodiversity across East Africa. http://www.academic journals.org/AJEST. Accessed on $02^{\text {nd }}$ August 2016.

Mugisha, J. and Alobo, S. 2012. Determinants of land management practices in the agricultural highlands of Uganda: A case of Kabale highlands in Western Uganda. Proceedings of the third RUFORUM Biennual Meeting, Entebbe, Uganda. pp. 923 -938.

Muzira, R., Vanlauwe, B., Basamba, T., Rwakaikara, C.M. and Wanjiku, C. 2014. Assessing the influence of farmers' field schools and market links on investments in soil fertility management under potato production in Uganda. In: Vanlauwe, D., Vanasten, P. and Blomme, G. (Eds.). Challenges and Opportunities for Agricultural Intensification of Humid Highland Systems of Sub-Saharan Africa pp. 281-294.

National Biomass study, Uganda 1996: Land cover Stratification (Vegetation), Uganda Forest Department, Kampala, Uganda.

Nkonya, E., Pender, J., Jagger, P., Sserunkuuma, D., Kaizzi, C. and Ssali, H. 2004. Strategies for Sustainable Land Management and Poverty Reduction in Uganda. Research Report 133, International Food Policy Research Institute (IFPRI), Washington, DC.
Nkonya, E. Pander, J., Kaizzi, C., Kato, E., and Mugarura, S. 2005. Policy options for increasing crop productivity and reducing soil nutrient depletion and poverty in Uganda. EPT Discussion Paper 134. IFPRI, Environment and Production Technology Division. https://books.google. com/kooks?id-xoezuccpslQC. Accessed on 26th August 2016.

Obua, J. and Agea, J.G. 2010. Forests and agroforestry in Uganda. In: Bongers, F. and Tennigkeit, T. (Eds.). Degraded forests in Eastern Africa: Management and Restoration. Earthscan Ltd., CrossStreet, London, UK. pp. 65-88.

Osiru, D.S.O. 2006. Report on Crop/Farming Systems and PRA. FAO Transboundary Agro-ecosystem Management Programme (TAMP). www.fao.org/ugcropfarming/ systems. Accessed on 26 $6^{\text {th }}$ April 2016.

Oslen, J. and Berry, L. 2003. Land degradation in Uganda: Its extent and impact. Accessed on $20^{\text {th }}$ October 2015 from: http:// earthmind.net/slm/docs/uganda/docs/ olson-berry-2003-uganda-ld.pdf papers/B/ . Accessed on 14 ${ }^{\text {th }}$ August 2016.

Pender, J., Jagger, P., Nkonya, E. and Sserunkuuma, D. 2002. Development pathways and land management in Uganda: Causes and implications. In: () Policies for improved land management in Uganda: Second National Workshop, EPTD Workshop Summary Paper No. 12. Environment and Production Technology Division, International Food Policy Research Institute, 2033 K Street, N.W., Washington, D.C. 20006 U.S.A.

Sabiiti, P. and Mutabazi, S. 2000. Kabale: District wetland Inventory, Ministry of Water, Lands and Environment. www.mwe.go.ug/index.php?option= com_dommac\&task $=$ doc. Accessed on $3^{\text {rd }}$ July 2016.

The World Bank Group 2017. Climate Change Knowledge Portal for Development Practitioners and Policy Makers. http:// sdwebx.worldbank.org/climateportal/ 
index.cfm?page=country historical climate Yuan, F., Bauer, M.E., Heinert, N.J. and \&This CCode=UGA. Accessed on $3^{\text {rd }}$ June 2017.

UBOS, Uganda Bureau of Statistics, 2012. Kabale District Local Government Statistical Abstract 2012, p. 3. Accessed on $11^{\text {th }}$ October 2015. www.ubos.org/ onlinefiles/uploads/ubos/2009_HLG Abstract_printed/CIS+UPLOADS/Higher Local Government Statistical Abstracts, 2012/Kabale.

Were, J. 1997. Land use and land degradation Holden, G. 2005. Multi-level land cover mapping of the Twin Cities (Minnesota) metropolitan area with multi-seasonal Landsat TM/ETM+data. Geocarto International 20(2): 5 -14.

Zhong, C. and Zhao, Z. 2005. A multi-scale remote sensing image segmentation algorithm based on region growing (in Chinese). Computer Engineering and Applications 35: 7-9.

in Kabale District, Uganda. East African Geographical Review 19(1):9-13. 